\title{
Ethological studies of native Mexican mammals: A review
}

\author{
Elaine Mariana Méndez-Muñiz¹, Michael J. Jowers², Samer Angelone³ ${ }^{3}$ and Luis Manuel Guevara-Chumacero ${ }^{1 *}$ \\ 1 Departamento de Biología, Universidad Autónoma Metropolitana-Iztapalapa. Avenida San Rafael Atlixco 186, CP. 09340. Ciu- \\ dad de México, México. Email: ela130595@gmail.com (EMM-M),Imgc@xanum.uam.mx (LMG-C). \\ ${ }^{2} \mathrm{CIBIO} / \mathrm{InBIO}$ (Centro de Investigación en Biodiversidad y Recursos Genéticos), Universidad de Oporto, Campus Agrario de Vairão, \\ 4485-661. Vairão, Portugal. Email: michaeljowers@hotmail.com (MJJ). \\ ${ }^{3}$ Instituto de Biología Evolutiva y Estudios Ambientales, Universidad de Zürich, Winterthurerstrasse 190. Zürich, Suiza. Email: \\ samer.angelone@gmail.com (SA). \\ *Corresponding author
}

The number of ethological studies based on Mexican mammals have increased in recent years compared to those from other Latin American countries. This study conducts an analytical review of the literature on ethological studies of native Mexican mammals. Specialized publications and electronic bibliographic databases were thoroughly searched to identify ethological studies of Mexican mammals published in scientific journals between 1900 and 2018. Information on the collection locality, state, first author nationality, country of origin of the journal, and taxa studied were recorded for each article. The articles were then classified into the 12 major ethological fields, and their data were grouped and summarized in five-year periods, and a map showing the geographic distribution of the studied localities was built using QGIS. A total of 160 studies were identified; three distinct periods could be recognized: the first (1900 to 1953) with a lack of publications, the second (1954 to1995) with low production $(n=16)$, and the third (1996 to 2018) with a notable increase in published articles $(n=144)$; in general, there was a greater participation of Mexican authors (67.5\%). Most studies (> $70 \%$ ) focused on primates, rodents, bats, and carnivores. Veracruz is the entity with the most articles, while foraging, movement, nesting, rearing, and territorial behavior were the subjects most studied, followed by social behavior, cooperation, and kinship. The greater number of studies published in the past two decades is likely the result of an increased number of mammologists and their engagement in national and international collaborative partnerships, mainly in areas such as ecology and taxonomy. Despite a relatively recent development of the field in México, an absence of studies on half of all terrestrial mammals orders, and few studies throughout northern parts of the country, mammalian ethology in México has already made significant contributions and is highly likely to continue its development and consolidation.

Los estudios de etología en mamíferos de México han repuntado en los últimos años con respecto a otros países latinoamericanos. El objetivo de este trabajo es elaborar un análisis bibliográfico de dichos estudios con enfoque etológico realizados con mamíferos nativos de México. Se obtuvo la bibliografía de estudios entre 1900 y 2018 sobre la etología de mamíferos de México con base en revistas periódicas, mediante la búsqueda en revistas especializadas y en bases de datos electrónicas. De cada artículo se registraron campos como: lugar de colecta, entidad federativa, nacionalidad del autor principal, origen de la revista y taxones trabajados, y se agruparon en uno de los doce temas etológicos principales. Con el programa QGIS se elaboró un mapa de las localidades de los estudios. Se registraron 160 trabajos que fueron distribuidos en tres periodos, el primero (1900 a 1953) con nula producción, el segundo (1954 a 1995) con baja producción ( $n=16)$ y el tercero (1996 a 2018) con un incremento notable en la publicación de artículos ( $n=144)$; en general, se presentó una mayor participación de autores nacionales (67.5\%). La mayoría de los trabajos (> 70\%) se han enfocado en el estudio de primates, roedores, quirópteros y carnívoros; Veracruz es la entidad federativa con más trabajos; mientras que, los temas más estudiados han sido sobre forrajeo, movimiento, anidación, crianza y territorialidad, así como comportamiento social, cooperación y parentesco. El incremento del número de publicaciones principalmente en las últimas dos décadas se puede deber al aumento de mastoozoólogos y al establecimiento de colaboraciones nacionales e internacionales, principalmente en áreas como la ecología y la taxonomía. Aunque es una ciencia relativamente joven en México, y a pesar de la ausencia de estudios en la mitad de los órdenes de mamíferos terrestres y en la parte norte del país, el campo de la etología de mamíferos de México cuenta con un número importante de contribuciones y es muy probable que el desarrollo de esta área del conocimiento continúe en el proceso de crecimiento y consolidación.

Keywords: Behavior; ethology; land mammals; México.

๑ 2021 Asociación Mexicana de Mastozoología, www.mastozoologiamexicana.org

\section{Introduction}

Traditionally, ethology has been defined as an approach to the study of animal behavior, derived from the discovery of instinctive movements (Eibl-Ebesfeldt 1975; Moreno and Muñoz-Delgado 2007; Breed and Moore 2012). This scientific discipline emerged from the interest in deepening the knowledge of animal behavior and understanding the variety of behaviors displayed by different species under dif- ferent conditions (Carranza 2010). Ethology focuses on the study of behavior, understood as an exchange mechanism between the organism and its environment under natural conditions (Díaz 1994; Medawar and Medawar 1996).

The earliest ethological studies conducted in México were carried out by ecologists and taxonomists interested in behavioral aspects of animals and their environment (Herrera 1986). Mammals exhibit a wide variety of life 
histories that make them suitable models for conducting ethological studies (e. g., Soares et al. 2016). Eleven orders, 36 families, 169 genera, and 503 species of terrestrial mammals have been recorded in México (Álvarez-Castañeda et al. 2015). According to Guevara-Chumacero et al. (2001), very few studies on Mexican mammals have addressed behavior as the primary study field: only $0.6 \%$ of the 1826 scientific articles published between 1890 and 1995 did so. The earliest clearly ethological studies on Mexican mammals addressed a diverse range of issues and taxa. For example, Russell and Findley (1954) described the swimming of a rodent of the genus Onychomys in the northern part of the country (State of Nuevo León), and Packard (1958) described carnivory behavior in the Mexican ground squirrel (Ictidomys mexicanus) in the State of Coahuila. Wimsatt (1969) described foraging and refuge selection by the common vampire bat (Desmodus rotundus) in the State of Tabasco, southern México, and Greenhall et al. (1971) documented the attack mode of this species on cattle in the State of Oaxaca. As these examples show, early ethological studies were observational and descriptive. These same study areas were explored in other Latin American countries prior to the adoption of experimental approaches (Jaffe et al. 2020). However, recent ethological studies from Latin America and other parts of the world (e. g., Europe and Australia) have used rigorous experimental methods based on hypothesis testing (Hoffmann et al. 2018; Morete et al. 2018; Wierucka et al. 2018; Mazza et al. 2020).

The available data indicate that ethological studies have recently become more prominent in México and Brazil than in other Latin American countries. However, an increase in the number of ethological studies over time is evident throughout Latin America, as interest in the academic discipline of animal behavior has grown in recent years (Jaffe et al. 2020).

Although México has been an important contributor to ethological studies, the progress made to date and direction taken by this type of studies in Mexican mammalogy have not been documented. Therefore, this study conducts an analytical review of the literature on ethological studies of native Mexican mammals. The objective of the study is to assess the wealth of information gathered to date and the path followed by this scientific discipline in México and based on this, to identify study subjects that need to be addressed by future efforts.

\section{Materials and methods}

Data gathering. An exhaustive search was conducted by consulting periodic journals on the bibliography concerning the ethology of mammals collected or observed in México between 1900 to 2018. We consulted the following websites: 1) Google Scholar (https://scholar.google.com/), 2) Clarivate Analytics - Web of science (https://clarivate. com/webofsciencegroup/) and 3) databases in bidiuam (https://bidi.uam.mx/bidi-ti/bases.html), such as: Biological Abstract, BioOne Complete, Current Contents Connect,
EBSCO, Nature, ProQuest, Science, Scopus, and Scielo. The used search keywords were: mammals, México, behaviour, behavior, conduct, ethology, homeostasis, circadian cycles, learning, cognition, communication, movement, foraging, self-defense, mating systems, nesting, rearing, territoriality, social behavior, conservation and behavior; these words were also combined, and used in Spanish. Each article compiled was reviewed in detail to identify whether it had an ethological approach as its main objective.

Processing of data. The information contained in the references was reviewed and organized in a database using EndNote Plus v. X 7.5 (Niles \& Associates, Inc). The fields used were: author, year, title, journal, volume, pages, language, nationality of the first author or corresponding author, federal entity, order, family, genus, species, location in geographical coordinates, state (wild, captive, semi-captive), subject of study, the Mexican institution affiliation of first or corresponding author, and the risk category according to the Mexican Official Standard (SEMARNAT 2010), the IUCN Red List of Threatened Species (Red List) and the Convention on International Trade in Endangered Species of Wild Fauna and Flora (CITES).

Study locations. For each article, the locality/localities where the observations were performed or the place where the data of the individuals studied in captivity was collected, and were registered for the Mexican state and the geographic coordinates (in decimal degrees). When not included in the publications, the mentioned localities were georeferenced in Google Earth (Lisle 2006). Using opensource Geographic Information System QGIS 2018 v. 3.4.4, a map of the localities was prepared, using as a base layer the State Political Division (2018), available in the Geoportal of the National Commission for the Knowledge and Use of Biodiversity (CONABIO).

Data analysis. To view research trends in detail, the data was split into periods of five years (Lustrums), except for the last period that covers three years. When the corresponding author was absent, the main author was considered as first author. In addition, the authors were classified as national or foreign according to the country of origin. A grouping was also made according to the origin of the journal (national or foreign).

Each publication was grouped into one of the 12 main ethological fields (Table 1) following Breed and Moore (2012). In addition, the publications were grouped according to the Mexican state where each study was carried out. In this work we follow the taxonomic nomenclature proposed by Álvarez-Castañeda (2015).

\section{Results}

One hundred and sixty-seven published scientific articles were registered between 1900 and 2018, with no productivity between 1900 to 1953 , and a low productivity in the first forty years (1954 to 1995) with only 16 papers. On the other hand, in the period between 1996 to 2018, there was 
Table 1. List of ethological studies according to Breed and Moore's categories (2012).

Fields

Homeostasis and time budgets
Learning
Cognition
Communication
Movement
Foraging
Self-defense
Mating systems
Nesting, rearing, and territoriality
Cocial behavior, cooperation, and kinship
Conservation and behavior

Subfields

Biological clock and circadian cycles, homeostatic regulation, time budgets and trade-offs.

Learning and memory, social learning, play, learning and development.

Concept of self, thinking, predicting, and solving problems, intelligence and social cognition, personality and behavioral syndrome, impulse control, animal emotions.

Evolution of communication, types of communication, out-of-control sexual selection and signaling, deception and honest communication, game theory and communication, interspecific signaling.

Searching, homing (ability to return to a territory after leaving it), migration, dispersal.

Diet and food choice, obtaining food, food disposal, prey handling, parasite cycles, foraging and optimization theory, optimal patch choice, prey choice.

Cryptic behavior and camouflage, surveillance and alarm, mimicry and deviance, evasion, predator deterrence and response to attack, pathogen avoidance, deterrence behavior and disease.

Sexual selection, variation in mating event, choice of male, hormones and sexual behavior, hormones territoriality and aggression, sperm competition, forced copulations, models of good genes for choosing a male.

Nests and nesting, parental investment, parental care patterns, hormones and parental care, parenting, and conflict of interest, begging and weaning conflict, sibling conflict, infanticide, aggression, and territoriality.

Altruism and self-interest, herds and hordes, cooperation, eusociality, social recognition.

To elucidate the differences of a specific behavior in different species.

Integration of the other fields to obtain useful information for conservation. a notable increase in published articles ( $n=144 ; 90 \%$ of the total; Figure 1). In general, Mexican authors (108 articles, $67.5 \%$ ) had a more active participation that foreign authors $(52,32.5 \%$, respectively).

Studies were published in 51 different journals (40 included in the Journal Citation Reports 2018 of Institute for Scientific Information - ISI) from 14 countries, 7 of Mexican origin and 44 foreign ( $33 \%$ corresponded to the United States). The journals with the highest number of publications were American Journal of Primatology $(n=16)$, Journal of Mammalogy ( $n=15)$, and International Journal of Primatology $(n=14)$. Among the Mexican journals, Acta Zoológica Mexicana (nueva serie) and Therya had the highest number of publications with 9 publications, each (Table 2).

In total the studies were based on 54 species from 16 families and 6 orders. The most studied species belonged to the order Primates and were Ateles geoffroyi, Alouatta palliata and A. pigra, with $43.6 \%$ of the publications. Other orders were Rodentia (21.5\%), Chiroptera (15.4\%), Carnivora (15.4\%), Lagomorpha (2.1\%) and Cetoartiodactyla (2.1 $\%$; Table 3). Of the 54 species, 10 are endemic to México and 17 species have some category of risk at the national or international level.

Articles were recorded for 23 Mexican states, with Veracruz $(n=31)$, Chiapas $(n=21)$, Quintana Roo $(n=20)$, totalling $43 \%$ of all studies. States such as Aguascalientes, Nayarit, Sinaloa, Tlaxcala, among others, lack any studies (Figure 2). Sixty percent of the studies focused on foraging, movement, nesting, rearing and territoriality, social behavior, cooperation, and kinship, while only $2.4 \%$ had as main objective the fields of learning and cognition (Figure 3).

\section{Discussion}

The publication rate of ethological studies of Mexican mammals varied considerably over the study period (1900 to 2018). We are aware of the probability that some gray literature articles might have not been considered, although it should not affect the trends presented. No production was recorded between 1900 to 1953, while very few studies were published $(n=16)$ between 1954 and 1995. This is consistent with the findings of Guevara-Chumacero et al. (2001) who found that only $0.6 \%$ of the 1826 articles on Mexican terrestrial mammals that were published during the period from 1890 to 1995 dealt with behavioral studies. The number of publications increased noticeably since 1996 (Figure 1); one hundred and forty-four were published during 1996 to 2018. This increase, mostly in the last decade of the $20^{\text {th }}$ century, is the result of increasing specialists in mammalogy and their engagement in interdisciplinary collaborations (Ramírez-Pulido et al. 2017), mainly in areas such as ecology and taxonomy (Cordero 1994) throughout México. In the second period, foreign authors had a more important role of participation than national authors. While in the third period, the national authors were the main authors of the studies (figure not shown). Institutions such as the Instituto de Neuroetología of the Universidad Veracruzana, Instituto Nacional de Psiquiatría Ramón de la Fuente Muñiz, El Colegio de la Frontera SurCampeche, as well as Facultad de Estudios Profesionales Superiores Iztacala, Estación de Biología Tropical Los Tuxtlas, and the institutes of Biology and Ecology of Universidad Nacional Autónoma de México (UNAM), have played a key role in this growing trend. 


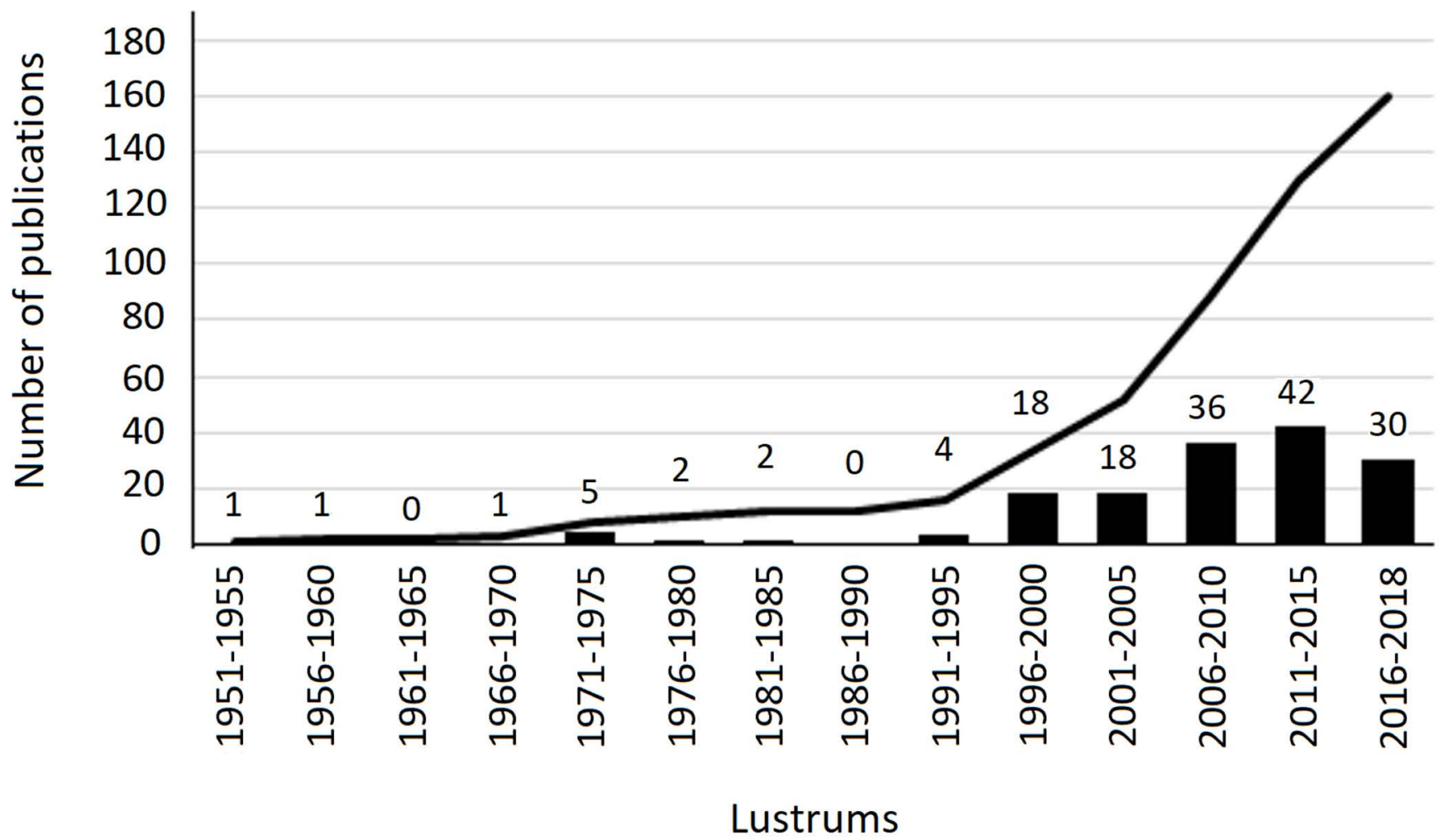

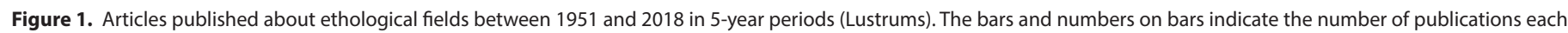
five years, and the line indicates the cumulative increase in publications.

A large proportion of papers ( $82.5 \%$ ) were published in international, non-Mexican journals, most of which (84\%) are indexed in the Journal Citation Reports - ISI. Not surprisingly, journals specialized in primatology (e. g., American Journal of Primatology, International Journal of Primatology, Primates, Folia Primatologica, and others) stand out, as over half of all articles have focused on the order Primates.

Primatology studies of native Mexican species began with several ecological and behavioral studies carried out at Los Tuxtlas Biological Station, in the State of Veracruz (e. g., Estrada 1984). Eighty-four percent of the original vegetation of the Los Tuxtlas region has been either lost or fragmented (Dirzo and García 1992; Dirzo et al. 2009); consequently, local populations of primate species have also been significantly reduced (Escobedo-Morales and Mandujano 2007). The proper design of conservation strategies requires up-to-date information on aspects such as the geographic distribution (Estrada 1982; Estrada and CoatesEstrada 1988) and ethology (Estrada et al. 1999; Juan et al. 2000) of the species. As a result, Veracruz is the Mexican state where the highest number of ethological studies ( $n=$ 31) have been conducted.

Most records of ethological studies are concentrated in the southeast part of the country, roughly matching the geographic distribution of Mexican primates (Figure 2). Ateles geoffroyi, Alouatta palliata, and A. pigra were the most common species studied, with more than $40 \%$ of the publications. In addition, the study of primates such as Ateles and Alouatta is key for understanding the development and evolution of the human species (e. g., Emery Thompson 2019) and is a cornerstone for conserving the tropical ecosystems they inhabit, given their role as umbrella species (Rodríguez-Luna et al. 2013). Finally, primates are charismatic species whose knowledge can contribute to attract support for conservation projects (Hill 2002).

Although with a much modest contribution in publications, the orders Rodentia, Carnivora and Chiroptera follow the order Primates ethological studies. The volcano mouse (Neotomodon alstoni), an endemic species from central México, is the most studied rodent because its social nature and omnivorous diet facilitates its study in captivity (e. g., Luis et al. 2000, 2012, 2017). The puma (Puma concolor), the jaguar (Panthera onca) and the Mexican wolf (Canis lupus baileyi) were the most heavily studied carnivores because they are emblematic, charismatic species and because are in some risk category (the last two; e. g., Servín 1991, 1997; Servín and Huxley 1991; Hernández-SaintMartín et al. 2015; De la Torre et al. 2017). The Jamaican fruit-eating bat (Artibeus jamaicensis) has attracted attention due to its dynamics of harem groups presented (Ortega and Arita 1999; Ortega and Maldonado 2006), and the vampire bat (Desmodus rotundus) for attacking cattle (Wimsatt 1969; Greenhall et al. 1971). Half of México's land mammal orders (Didelphimorphia, Cingulata, Perissodactyla, Pilosa, Soricomorpha) are not the subject of ethology studies.

Ethology became established as a scientific discipline on its own right worldwide in 1973 (Moreno and MuñozDelgado 2007). Prior to that year, only six articles had been 


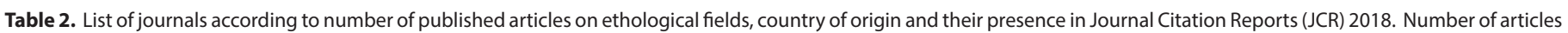
(No.). Country of origin (C.O.). JCR (presence: OK; absence: -).

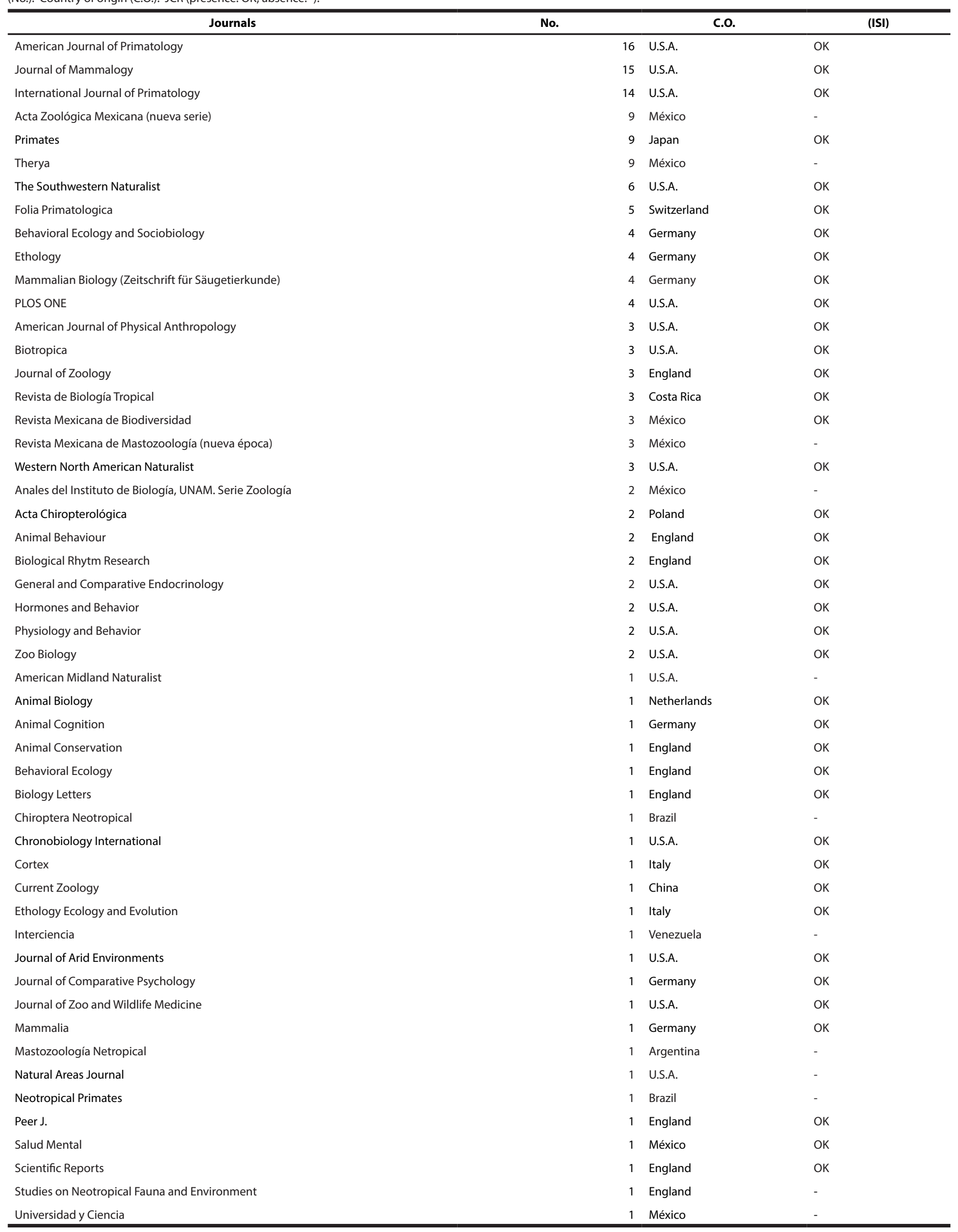




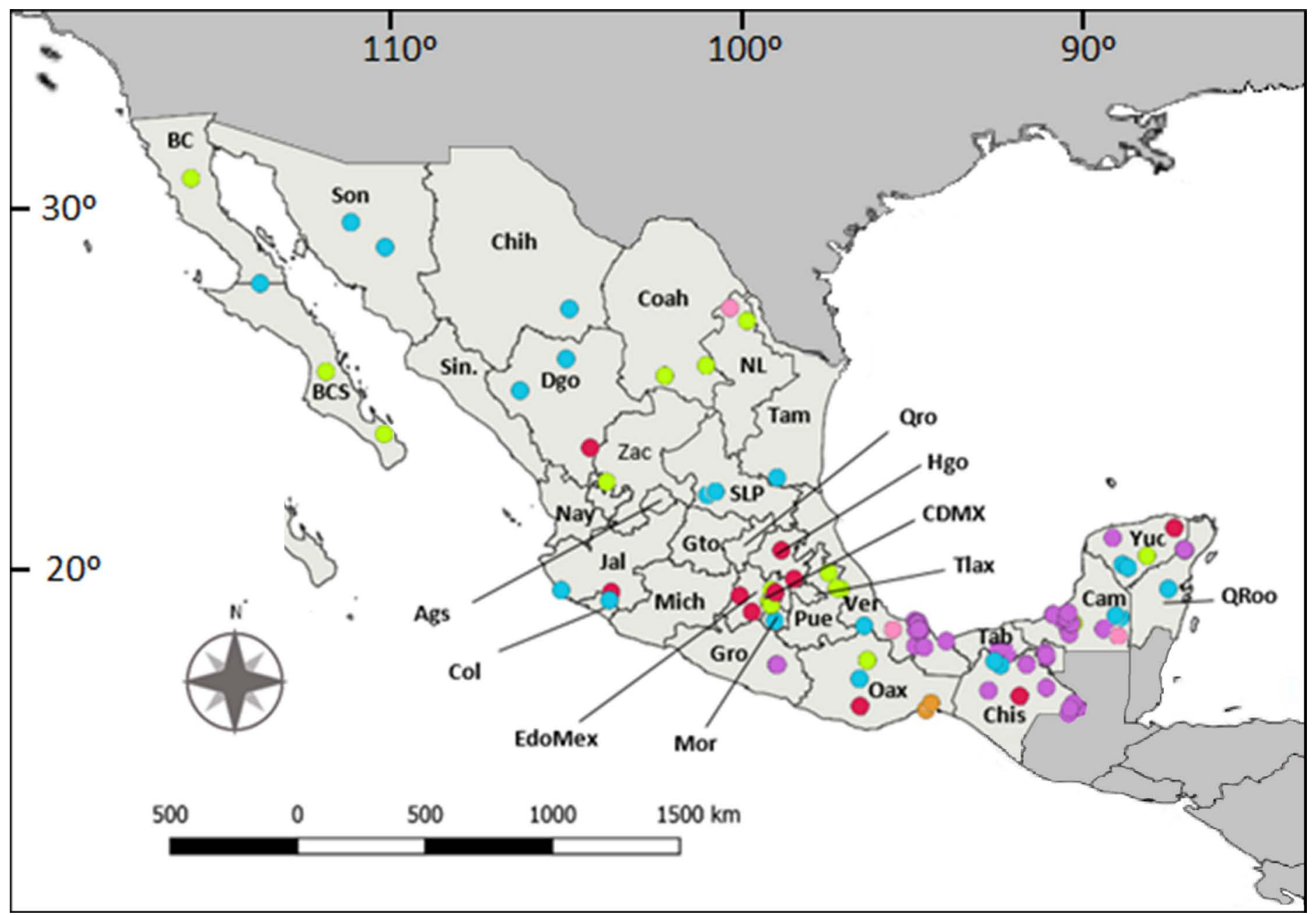

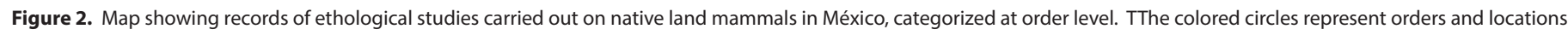

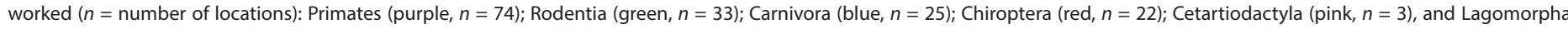

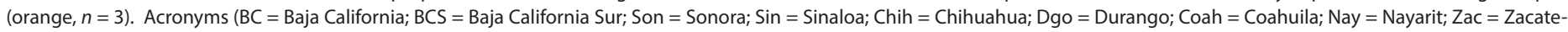

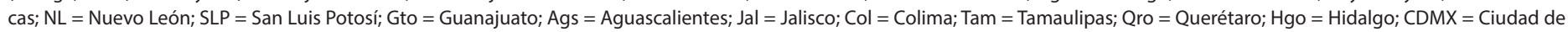

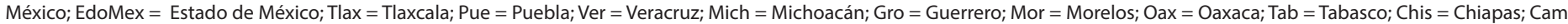
= Campeche; Yuc = Yucatán; QRoo = Quintana Roo).

published in México, most of them authored by foreign researchers. Those studies examined various ethological aspects of mammals. Russell and Findley (1954) documented the first observation of swimming of a myomorph rodent of the genus Onychomys from the State of Nuevo León. Packard (1958) described the carnivorous behavior of the Mexican ground squirrel (Ictidomys mexicanus) preying on a rabbit (Sylvilagus sp.) in the State of Coahuila. Other studies described various aspects of the common vampire bat, Desmodus rotundus: foraging behavior and refuge selection in the State of Tabasco (Wimsatt 1969), mode of attack on cattle in the State of Oaxaca (Greenhall et al. 1971), biting and feeding habits in captivity at the Instituto Nacional de Investigaciones Pecuarias in México City (Greenhall 1972), and the relationship between the feeding periods and absence in relation to moonlight in Oaxaca and San Luis Potosí (Crespo et al. 1972).

Thirteen scientific papers were published between 1973 and 1995. For example, Gould (1975) recorded, described, and compared vocalization patterns related to precocial and altricial conditions of pups of eight bat species, including two from México (the lesser long-nosed bat, Leptonycteris yerbabuenae, from Sonora, and the black mastiff bat, Molossus rufus, collected by R. Horst and recorded at his laboratory). The mating behavior of four deer-mouse species of the genus Peromyscus from Oaxaca and Campeche was described by Dewsbury (1979). The diurnal roosting and resting behavior (in tree holes) of the Mexican fruit bat (Artibeus jamaicensis) at Chamela Biological Station, Jalisco, was described by Morrison (1979). Estrada (1984) and Estrada and Coates-Estrada (1985) studied the frugivory habits and range of habitats used by the mantled howler (Alouatta palliata) in Los Tuxtlas, Veracruz. Servín (1991) described 37 social behavioral patterns (classified into friendly, submissive, playful, sexual, and aggressive-defensive behaviors) displayed by five Mexican wolves (Canis lupus baileyi) over 15 months in captivity in the State of Durango. Servín and Huxley (1991) determined the seasonal and annual foods habits of coyote Canis latrans by analizing 330 scats collected on the buffer zone at the Michilia Biosphere Reserve, 


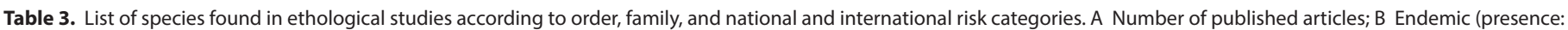

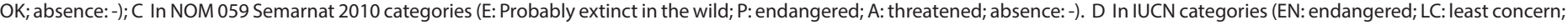
VU: vulnerable; NT: near threatened; absence: -). E In CITES Appendices (I: Highly endangered; II: may become endangered; absence: -).

\begin{tabular}{|c|c|c|c|c|c|c|c|}
\hline Order & Family & Species & A & B & C & D & $\mathbf{E}$ \\
\hline \multicolumn{8}{|c|}{ Primates } \\
\hline \multirow{3}{*}{\multicolumn{2}{|c|}{ Atelidae }} & Ateles geoffroyi & 37 & - & $\mathrm{P}$ & EN & I, II \\
\hline & & Alouatta pigra & 25 & - & $\mathrm{P}$ & LC & 1 \\
\hline & & Alouatta palliata & 23 & - & $\mathrm{P}$ & EN & 1 \\
\hline \multicolumn{8}{|c|}{ Rodentia } \\
\hline \multirow{12}{*}{\multicolumn{2}{|c|}{ Cricetidae }} & Neotomodon alstoni & 12 & OK & - & LC & - \\
\hline & & Neotoma mexicana & 1 & - & - & $\mathrm{LC}$ & - \\
\hline & & Microtus mexicanus & 2 & - & - & $\mathrm{LC}$ & - \\
\hline & & Onychomys leucogaster & 1 & - & - & LC & - \\
\hline & & Peromyscus aztecus & 1 & - & - & $\mathrm{LC}$ & - \\
\hline & & Peromyscus melanocarpus & 1 & OK & - & EN & - \\
\hline & & Peromyscus melanophrys & 2 & OK & - & $\mathrm{LC}$ & - \\
\hline & & Peromyscus mexicanus & 1 & - & - & LC & - \\
\hline & & Peromyscus melanotis & 1 & OK & - & $\mathrm{LC}$ & - \\
\hline & & Peromyscus yucatanicus & 2 & - & - & LC & - \\
\hline & & Reithrodontomys megalotis & 2 & - & - & $\mathrm{LC}$ & - \\
\hline & & Sigmodon leucotis & 1 & - & - & LC & - \\
\hline \multirow{4}{*}{\multicolumn{2}{|c|}{ Heteromyidae }} & Chaetodipus siccus & 3 & OK & $A$ & $\mathrm{LC}$ & - \\
\hline & & Dipodomys merriami & 1 & - & $A$ & $\mathrm{LC}$ & - \\
\hline & & Heteromys gaumeri & 2 & - & - & LC & - \\
\hline & & Heteromys irroratus & 1 & - & - & $\mathrm{LC}$ & - \\
\hline \multirow{5}{*}{\multicolumn{2}{|c|}{ Sciuridae }} & Cynomys mexicanus & 1 & OK & $P$ & EN & I \\
\hline & & Ictidomys mexicanus & 2 & OK & - & $\mathrm{LC}$ & - \\
\hline & & Ictidomys spilosoma & 1 & - & - & LC & - \\
\hline & & Tamiasciurus mearnsi & 1 & OK & A & EN & - \\
\hline & & Xerospermophilus perotensis & 2 & OK & A & EN & - \\
\hline \multicolumn{8}{|c|}{ Chiroptera } \\
\hline \multirow{2}{*}{\multicolumn{2}{|c|}{ Phyllostomidae }} & Artibeus jamaicensis & 6 & - & - & $\mathrm{LC}$ & - \\
\hline & & Anoura geoffroyi & 2 & - & - & LC & - \\
\hline
\end{tabular}

finding that mammals (e. g., rodents and ungulates) and fruits (e. g., Juniperus deppeana and Arctostapphyllos pungens.) were the most consumed food categories. In the same Biosphere Reserve, Servín and Huxley (1995) determined the home range of coyotes (Canis latrans), registering an average annual of $9.1 \mathrm{~km}^{2}$.

The most productive period by far was between 1996 and 2018 , with $90 \%$ of the articles retrieved were published over these years. The fields most frequently addressed were foraging with 33 articles (19.5\%), movement with 28articles (16.6\%) and nesting, rearing, and territoriality, and social behavior, cooperation, and kinship with 20 and 21 articles (12.4\% and $11.8 \%)$, respectively.

Thirty-three studies focused on foraging, examining for example food preferences and selection strategies of spider monkeys and howler monkeys at Los Tuxtlas, Veracruz (Dunn et al. 2009, 2010, 2012), Palenque, Chiapas (Amato et al. 2014), Catemaco, Veracruz (Reynoso-Cruz et al. 2016), and the Yucatán Peninsula (Pinacho-Guendulain and Ramos-

\begin{tabular}{|c|c|c|c|c|c|c|c|}
\hline Order & Family & Species & A & B & C & D & E \\
\hline & & Artibeus lituratus & 1 & - & - & LC & - \\
\hline & & Carollia sowelli & 1 & - & - & LC & - \\
\hline & & Desmodus rotundus & 6 & - & - & LC & - \\
\hline & & Diphylla ecaudata & 1 & - & - & LC & - \\
\hline & & Glossophaga commissarisi & 1 & - & - & LC & - \\
\hline & & Leptonycteris yerbabuenae & 3 & - & - & NT & - \\
\hline & Emballonuridae & Balantiopteryx plicata & 1 & - & - & LC & - \\
\hline & Molossidae & Molossus rufus & 1 & - & - & LC & - \\
\hline & & Nyctinomops laticaudatus & 1 & - & - & LC & - \\
\hline & Mormoopidae & Pteronotus gymnonotus & 1 & - & $A$ & LC & - \\
\hline & & Pteronotus mesoamericanus & 1 & - & - & LC & - \\
\hline & Vespertilionidae & Aeorestes cinereus & 1 & - & - & LC & - \\
\hline & & Antrozous pallidus & 1 & - & - & LC & - \\
\hline & & Lasiurus blossevillii & 1 & - & - & LC & - \\
\hline & & Lasiurus borealis & 1 & - & - & LC & - \\
\hline \multicolumn{8}{|c|}{ Carnivora } \\
\hline \multirow{3}{*}{\multicolumn{2}{|c|}{ Canidae }} & Canis lupus baileyi & 6 & - & $\mathrm{E}$ & LC & I, II \\
\hline & & Canis latrans & 5 & - & - & LC & - \\
\hline & & Urocyon cinereoargenteus & 1 & - & - & LC & - \\
\hline \multirow{3}{*}{\multicolumn{2}{|c|}{ Felidae }} & Lynx rufus & 3 & - & - & LC & $\|$ \\
\hline & & Puma concolor & 7 & - & - & LC & - \\
\hline & & Panthera onca & 6 & - & $P$ & NT & 1 \\
\hline & Mephitidae & Conepatus leuconotus & 1 & - & - & LC & - \\
\hline & Procyonidae & Bassariscus astutus & 1 & - & A & LC & - \\
\hline \multicolumn{8}{|c|}{ Lagomorpha } \\
\hline & Leporidae & Lepus flavigularis & 4 & OK & $P$ & EN & - \\
\hline \multicolumn{8}{|c|}{ Artiodactyla } \\
\hline & Cervidae & Odocoileus virginianus & 3 & - & - & - & - \\
\hline & Tayassuidae & Tayassu pecari & 1 & - & $P$ & vu & $\|$ \\
\hline
\end{tabular}

Fernández 2017), as well as the use of non-conventional sources of water (e. g., streams) in Veracruz (Serio-Silva and Rico-Gray 2000) and Campeche (Duarte-Dias et al. 2014). The response of monkeys to variations in food availability was studied in a controlled environment at the Hilda Ávila de O'Farrill Management Unit, Veracruz (Rangel-Negrín et al. 2015) and in fragmented habitats at Los Tuxtlas, Veracruz (Estrada et al. 1999; Juan et al. 2000; Asensio et al. 2007), Balacán, Tabasco (Pozo-Montuy and Serio-Silva 2006), and the Lacandona tropical rainforest, Chiapas (Chaves et al. 2012; Benitez-Malvido et al. 2016). Horner et al. (1998) described that southern long-nosed bats, Leptonycteis curasoae, from the State of Sonora visited between 80 to 100 cactus flowers daily to feed on nectar and acquired 40 kilojoules of energy. Frick et al. (2009) documented, based on 143 working nights at 14 sites in Baja California, the first known example of an insectivorous bat, the pallid bat Antrozous pallidus, displaying facultative nectarivorous habits. Hernández-Hernández et al. (2018) found that the endemic Perote ground squir- 
rel, Xerospermophilus perotensis, feeds opportunistically but, under certain conditions, selects plant species that provide a better-quality diet; Luna-Casanova et al. (2016), for his part, determined the preference of Tehuantepec jackrabbit (Lepus flavigularis) in Oaxaca to establish feeding and resting sites in the pasture with the presence of cattle. The food habits, based on scats, of different carnivores were also determined, for example; the coyote (Canis latrans; Grajales-Tam et al. 2003), the puma (Puma concolor), and jaguar (Panthera onca; Aranda and Sánchez-Cordero 1996), and cacomixtle, (Bassariscus astutus; Nava et al. 1999), in different states such as Baja California Sur, Campeche, Hidalgo and San Luis Potosí.

Studies on movement $(n=28)$ focused on the use of space and movement patterns of animals, mostly in the Central American spider monkey (Ateles geoffroyi). Valero and Byrne (2007) worked in the Otochma'ax Yetel Kooh reserve (Yucatán) and found that these monkeys are guided by spatial memory and are capable of planning routes. Smith-Aguilar et al. (2016) found a more concentrated use of space and higher rates of association (individuals brought together by resources of common interest) during periods of high fruit abundance. Campbell et al. (2005) investigated the terrestrial behavior of spider monkeys at five study sites in Perú, Ecuador, Panama, Costa Rica, and México (Punta Laguna, Yucatán) and concluded that this behavior occurred rarely, being more restricted in South America, where it occurred only in the context of eating soil or rotten wood and visiting salt licks. This contrasted with the behavior observed in
Central and North America, where terrestrialism occurred more frequently while drinking water from streams during the dry season, when adult females escaped attacks by adult males, or as part of a chase game. Van-Belle et al. (2013) recorded, over 15 months, 691 movements of independent groups of another primate species, Alouatta pigra, at Palenque National Park, Chiapas, confirming that adult females showed leadership more frequently than males. Such female actions are beneficial for life as a group because they provide social cohesion by coordinating the timing and direction of travel, a behavior that has been observed in other mammals (Smith et al. 2015; Tokuyama and Furuichi 2017).

The home range has been determined in other terrestrial mammals for example the coyote (Canis latrans), in Durango (Servín and Huxley 1995) and Oaxaca (Marín-Sánchez et al. 2015), the gray fox (Urocyon cinereoargenteus), in Durango (Servín et al. 2014), the jaguar (Panthera onca) in Quintana Roo (González-Gallina et al. 2018), the Gaumer's spiny pocket mouse (Heteromys gaumeri), in Yucatán (Cimé-Pool et al. 2002; Hernández-Betancourt et al. 2003), the Mexican spiny pocket mouse (Heteromys irroratus) in Oaxaca (SantosMoreno and Santiago-Marcial 2012), the bobcat (Lynx rufus) in Durango and Chihuahua (Elizalde-Arellano et al. 2012) and Colima (Burton et al. 2003), the Tehuantepec Jackrabbit (Lepus flavigularis) in Oaxaca (Carrillo-Reyes et al. 2010), the white-lipped peccaries (Tayassu pecari) in Campeche (ReynaHurtado et al. 2009), and the white-tailed deer (Odocoileus virginianus) in Nuevo León (Bello et al. 2004).

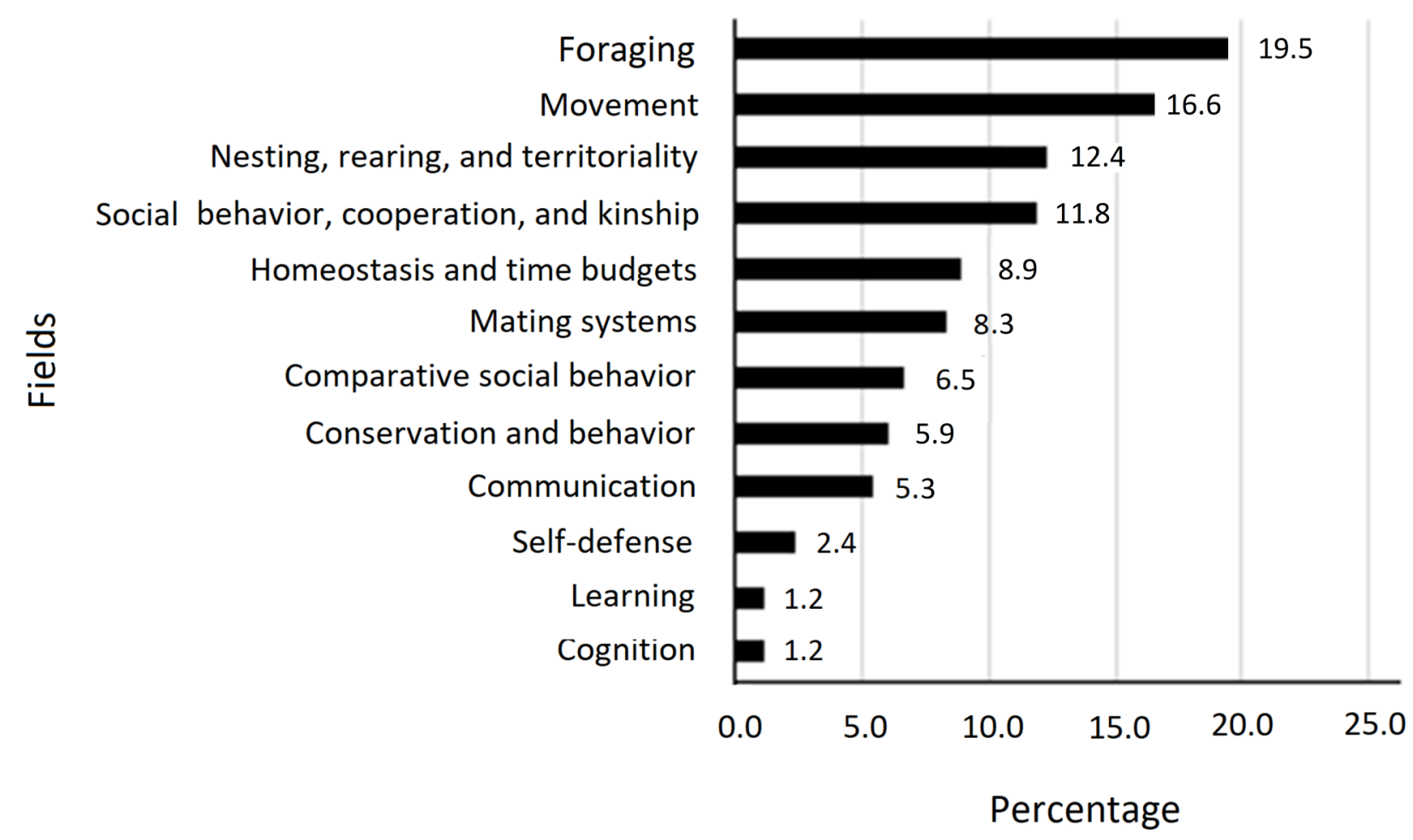

Figure 3. Percentage of published ethological articles organized by field based on Breed and Moore (2012). 
A genetic structure study by Aguilera-Miller (2016) on the Cerralvo pocket mouse, Chaetodipus siccus, a species endemic to the Baja California Peninsula, revealed that the ethological interactions between individuals (e. g., dominant females more aggressive than subordinates) were responsible for females not dispersing and remaining in small geographic areas, pointing to the presence of female philopatry. In addition, Aguilera-Miller et al. (2018), based on the same molecular markers, found that the haplotypes considered to be ancestral were located at the periphery of the distribution area, while the derived haplotypes were located in the center of the distribution range, supporting again the hypothesis of strong philopatric behavior among females.

The 21 studies on nesting, rearing, and territoriality addressed primarily parental care and aggressive behavior. For example, observations on the endemic Mexican volcano mouse (Neotomodon alstoni), in captivity in México City confirmed that this species exhibits monogamous and biparental care behaviors (Luis et al. 2000). Males looked after the offspring when their testosterone levels were high (Luis et al. 2009, 2012, 2017), and the presence of males adversely affected maternal care but improved offspring survival (Luis et al. 2004).

The reproductive behavior of the Tehuantepec jackrabbit (Lepus flavigularis), an endemic species listed as endangered in the official Mexican laws (SEMARNAT 2010), was studied by Rioja-Paradela et al. (2011) in the State of Oaxaca. These authors found that the breeding season lasted 250 days per year; each female gave birth to two leverets that were weaned after 12 days and showed a higher survival rate relative to other leporids; predation by feral dogs (Canis familiaris) appeared to be the primary cause of mortality. On the other hand, Servín (1997) determined that, in a captive population of Mexican wolves (Canis lupus baileyi) from the La Michilía Biosphere Reserve, Durango, the mating occurred from January to April, the births occurred between April and May and the average number of offspring born per litter was four.

Studies on primates showed that the Guatemalan black howler, Alouatta pigra, in the State of Campeche lengthens its foraging periods during lactation (Duarte-Dias et al. 2011); maternal care by the mantled howler monkey, $A$. palliata, in the State of Veracruz, was directly related to lactation stage and food availability (Duarte-Dias et al. 2018). Duarte-Dias (2005) provided a detailed description of labor and birth in A. palliata under semi-captivity conditions at Agaltepec island in Catemaco, Veracruz. He described the labor and birth stages, behavioral events, and their timing and duration; the patterns described are representative of the birth process in this species.

Other studies addressed aggressive patterns in spider monkeys (Ateles geoffroyi) from protected areas in Yucatán. Valero et al. (2006) recorded collective aggressions by sexually mature males towards a single younger individual, with a fatal outcome. Aureli et al. (2006) reported, for the first time, instances of assault groups advancing on the ground in unusual silence, similar to the behavior of chimpanzees (Kelly 2000; Watts et al. 2006). Although no fatal outcomes were observed, these behaviors may be related to factors such as reduction in mating opportunities, number of males relative to the neighboring community, or strengthening of intra-group ties. These findings suggest that this behavior might have evolved primarily through mutualism where participants gain direct benefits from their physical fitness. Intergroup aggression in defense of the cooperative group was observed in the Guatemalan black howler (A. pigra), at Palenque, Chiapas (Van-Belle et al. 2014); intragroup aggression, even including infanticide, was observed at Balancán, Tabasco (García-Feria et al. 2016).

The 20 studies on social behavior, cooperation, and kinship focused mostly on primates. Pastor-Nieto (2001) studied spider monkeys, Ateles geoffroyi, at the Zoológico Centenario zoo in Yucatán, finding that social relationships such as food sharing were influenced by affiliative behavior (e. g., mutual grooming) rather than by kinship. Social relationships were observed to improve the physical fitness of wild spider monkeys in the Yucatán Peninsula. For example, there was a closer proximity between family dyads, as well as between male-male relationships (Rebecchini et al. 2011); affiliative behaviors between males were found to be more common when they were young (Schaffner et al. 2012) and when new members entered the group and acted as bond initiators (Aureli and Schaffner 2007). Slater et al. (2009) found that competition for resources and the need for cooperation affected social interaction patterns, particularly the social relationships between females as they spent much time on feeding and showed greater aggressiveness. However, the presence of small infants influenced the social behavior of females as, according to Slater et al. (2007), mothers with infants received significantly more approaches and hugs from other females.

The fifteen behavioral studies on homeostasis and time budgets included a radiotelemetry study of activity patterns of the white-tailed deer (Odoicoileus virginianus), in a xerophilous scrub in the State of Coahuila (Gallina and Bello Gutiérrez 2014). A study of locomotor activity of the Mexican wolf (Canis lupus baileyi), in relation to lunar phases, which recorded the most intense activity during the waxing moon, decreasing activity during the full and last quarter moons, and the lowest locomotive activity during new moon (Sánchez-Ferrer et al. 2016). Other studies found interspecific differences in the way primates allocate time to different activities: the mantled howler monkey, $A$. palliata, spent a considerable amount of time resting, feeding, and moving around (Muñoz et al. 2001); Guatemalan black howlers ( $A$. pigra), rested more frequently in highquality habitats (Rangel-Negrín et al. 2018); separately, the periods of rest and activity of spider monkeys (A. geoffroyi), were mainly driven by light-darkness periods and environmental factors such as temperature, precipitation, and humidity (Muñoz-Delgado et al. 2004). In this last species, 
in Catemaco, Veracruz, Muñoz-Delgado et al. (2014) studied the impact of housing conditions and season on the daily timing and pattern, and Muñoz-Delgado et al. (2018), recorded that these primates respond to visitor (tourist) activity since it modified their normally pronounced bimodal diel activity pattern and developed a superimposed infradian activity rhythm peaking on Saturday and Sunday.

The 14 studies on mating systems included a study of the breeding season and reproductive behavior of the Mexican prairie dog (Cynomys mexicanus), in Coahuila (Rioja-Paradela et al. 2008a); an early effort to determine the mating behavior of the Tehuantepec jackrabbit (Lepus flavigularis), in the State of Oaxaca (Rioja-Paradela et al. 2008b); and the first report on the sexual behavior of the Mexican wolf (Canis lupus baileyi) at the San Juan de Aragón zoo (México City) in summer (Soto et al. 2013). All these species are listed as endangered (SEMARNAT 2010; Álvarez-Castañeda et al. 2019; Lorenzo and Smith 2019).

The structure and social interactions of bats and primates were also studied. Ortega and Arita (1999) found that Mexican fruit bats (Artibeus jamaicensis), from the Yucatán Peninsula formed harems consisting of 4 to 18 females and one or two males, where males could play different roles: dominant (one in each harem), subordinate (present only in large harems), or satellite (not associated with a harem). Dominant males actively defended females, particularly during the breeding season when they displayed more agonistic responses towards male visitors (Ortega and Arita 2000). However, some subordinate males may have associated with harems as satellites, provided that they contributed some benefit to the dominant male (Ortega and Arita 2002). In addition, Ortega and Martínez-Rodríguez (2011) registered that broad tailed bat (Nyctinomops laticaudatus) in the archaeological zone of Uxmal, Yucatán, shows a promiscuous mating system, and the males display agonistictype behavioral activities.

A study at the Palenque National Park (Tabasco, México) showed that the black howlers (Alouatta pigra) with high androgens levels and fecal glucocorticoids, had almost exclusive access to fertile females (Van-Belle et al. 2009a), in addition males rarely solicited sexual interactions, but instead monitored the females reproductive status by sniffing their genitals, and maintained significantly closer proximity to females during their periovulatory periods (Van-Belle et al. 2009b). In contrast, studies of spider monkeys (Ateles geoffroyi) from Yucatán found that males with fewer reproductive opportunities resorted to infanticide (Gibson et al. 2008) or attacked females (Slater et al. 2008), likely as a means of sexual coercion to increase their mating chances.

Studies on comparative social behavior $(n=11)$ addressed, for example, the role of agonistic behavior in explaining the relative abundance of the Mexican volcano mouse (Neotomodon alstoni), in a small mammal community at the Sierra del Ajusco mountain range in central México. Habitat partitioning by occupying different micro- habitats or maintaining discrete central areas were mechanisms likely allowing the coexistence of $\mathrm{N}$. alstoni and other species such as the black-eared mouse (Peromyscus melanotis), and the Mexican vole (Microtus mexicanus), which usually defended their territory in preferred microhabitats against $N$. alstoni (Fa et al. 1996). The first known cases of infanticide and forced copulation in spider monkeys ( $A$. geoffroyi) from two communities in México and four in Perú (Gibson et al. 2008) were also described. Gibson et al. 2008 and Hernández-Saintmartín et al. (2013) studied activity patterns of jaguars, pumas, and their potential prey species in San Luis Potosí, where the activity peaks of both felids suggest that temporal segregation is a strategy which minimizes interspecific encounters allowing the coexistence of several individuals.

The ten studies that focused on conservation and behavior looked only at primates, addressing the close relationship between anthropogenic disturbance factors and behavioral changes or increased stress levels in animals. Rangel-Negrín et al. (2016) found that Guatemalan black howlers (A. pigra) from the State of Campeche exhibited a narrower behavioral repertoire and higher psychosocial stress levels when living in altered or disturbed habitats. The latter was also observed in Guatemalan black howlers from the Yucatán Peninsula (Rangel-Negrín et al. 2014), Balancán, Tabasco (Martínez-Mota et al. 2007), and El Zapotal Ecological and Recreational Center, State of Veracruz (Aguilar-Melo et al. 2013), as a response to tourism in the latter. However, stress has also been recorded in A. palliata by translocations in southern Veracruz (Aguilar-Cucurachi et al. 2010).

However, these behaviors are not unique to howler monkeys. Spider monkeys ( $A$. geoffroyi) from an island in Catemaco lake, Veracruz, showed increased agonistic behaviors and fewer vocalizations in the presence of tourists (Pérez-Galicia et al. 2017). An alternative to address stressful behaviors in captivity was suggested by MárquezArias et al. (2014). They showed that, at the Instituto Nacional de Psiquiatría Ramón de la Fuente Muñiz in México City, environmental enrichment ameliorated behavioral issues caused by confinement.

The nine articles that addressed communication behavior looked mostly at vocalization aspects. Servín (2000) found that Mexican wolves (Canis lupus baileyi) in captivity at La Michilía, State of Durango, howled more frequently and for longer periods during mating, and were heard more often at dawn and dusk. A comparison of two groups of spider monkeys (Ateles geoffroyi) from México and Costa Rica revealed that contact calls in each group showed differential variations between individuals (Santorelli et al. 2013). On the other hand, the studies by Briseño-Jaramillo et al. $(2015,2017,2018)$ on Guatemalan black howlers ( $A$. pigra) from Yucatán, provided the first description of a unique behavior associated with the call (placing a hand in front of the mouth while vocalizing), a study that opened up a new line of research on how non-human primates 
developed strategies to overcome limitations in acoustic plasticity. These authors identified a repertoire of vocal calls that included twelve distinct calls (three of which are emitted exclusively by females and two only by males) and confirmed the presence of non-random patterns through which individual calls can be differentiated, even those from members of other groups, which might represent potential "conversation rules" (Briseño-Jaramillo et al. 2018).

Self-defense $(n=4)$, learning $(n=2)$, and cognition $(n=$ 2) were studied least frequently; altogether, they accounted for less than $5 \%$ of the articles published during this period. Studies on self-defense described aspects such as the evasive behavior of $A$. palliata towards a group of the potential predator tayra, Eira barbara, in Playa Escondida, Veracruz (Asensio and Gómez-Marín 2002) and climbing more than $5 \mathrm{~m}$ as an escape mechanism of the American hog-nosed skunk (Conepatus leuconotus), when chased by humans in Colima (México) and Texas (USA; Brashear et al. 2010).

Finally, the articles on learning addressed the cultural transmission of behavior in primates. For example, Santorelli et al. (2011) compared variants of universal behaviors (defined as those used across all communities) of spider monkeys at three communities, two in Punta Laguna, Yucatán, México and one in Santa Rosa, Costa Rica. Six behaviors were identified that were likely maintained through social learning: 1) fruit extraction using the hand instead of the mouth; 2) drinking by licking instead of dribbling; 3) drinking using the left hand instead of the right hand; 4) contact greeting instead of non-contact greeting; 5 ) resting sitting upright; and 6) resting by leaning laterally. These results may have several implications for the study of spider monkey behavior: on the one hand, they suggest the possibility of a behavioral repertoire larger than the one reported by previous studies (e. g., McGrew 1998; Watson and Caldwell 2009); on the other, that the relative use of universal behavioral variants can reinforce community membership.

Briseño-Jaramillo et al. (2015) provided the first description of a unique behavior (placing a hand in front of the mouth while vocalizing) associated with the call of Guatemalan black howlers at Palenque National Park, Chiapas. They concluded that this behavior is transmitted culturally and plays a role in intergroup competition and intragroup cohesion.

In conclusion, ethological research on mammals in México - as represented by published articles in which this was the main study subject - reveals three distinct periods: the first (1900 to 1953) with no published papers, the second (1954 to 1995) was characterized by a low production of publications, while the third (1996 to 2018) shows a linear increase in the number of articles published, usually in foreign journals, with Mexican authors having an increasing participation. More than $90 \%$ of all the studies focused on primates, rodents, bats, and carnivores and most studies were developed in the State of Veracruz and southeast México. Ethological studies have not explored other mammalian orders nor have focused on the north- ern part of the country. A diverse set of studies have been addressed, particularly over the last two decades; those such as foraging, movement, nesting, breeding, and territoriality, followed by social behavior, cooperation and kinship stand out in terms of the number of articles published. Despite its relatively recent development compared to disciplines such as paleontology, evolution, biogeography, and others, mammalian ethology in México has already made significant contributions given the growing number of mammalogists interested in this field and the increase in national and international collaborations, which therefore indicates that mammal ethology will surely continue its development and consolidation.

\section{Acknowledgments}

The authors are grateful for the administrative and logistic support of the Department of Biology, Universidad Autónoma Metropolitana, Campus Iztapalapa (México City). In memory of A. Serrato Díaz; a great academic and friend. Who passed away days before the publication of this manuscript.

\section{Literature cited}

Aguilar-Cucurachi, M. S., P. A. Dias, A. Rangel-Negrín, R. Chavira, L. Boeck, and D. Canales-Espinosa. 2010. Preliminary evidence of accumulation of stress during translocation in mantled howlers. American Journal of Primatology 72:805-810.

Aguilar-Melo, A. R., E. Andresen, J. Cristóbal-Azkarate, V. Arroyo-Rodríguez, R. Chavira, J. Schondube, J. C. Serio-SilVA, AND A. D. Cuarón. 2013. Behavioral and physiological responses to subgroup size and number of people in howler monkeys inhabiting a forest fragment used for nature-based tourism. American Journal of Primatology 75:1108-1116.

Aguilera-Miller, E. F. 2016. Ethology may be related to the genetic structure of a population: Chaetodipus siccus as a study case. Therya 7:371-392.

Aguilera-Miller, E. F., S. T. Álvarez-Castañeda, and R. W. MurPHY. 2018. Matrilineal genealogies suggest a very low dispersal in desert rodent females. Journal of Arid Environments 152:28-36.

Álvarez-Castañeda, S.T., T. Álvarez, and N. González-Ruiz. 2015. Guía para identificar los mamíferos de México. AMMAC. Guadalajara, México.

Álvarez-Castañeda, S. T., T. Lacher, and E. Vázquez. 2019. Cynomys mexicanus. The IUCN Red List of Threatened Species 2019: e.T6089A139607891. https://dx.doi.org/10.2305/ IUCN.UK.2019-3.RLTS.T6089A139607891.en. Downloaded on 13 November 2020.

Amato, K. R., AND P. A. Garber. 2014. Nutrition and foraging strategies of the black howler monkey (Alouatta pigra) in Palenque National Park, México. American Journal of Primatology 76:774-787.

Aranda, M., and V. Sánchez-Cordero. 1996. Prey spectra of jaguar (Panthera onca) and puma (Puma concolor) in tropical forests of México. Studies on Neotropical Fauna and Environment 31:65-67. 
Asensio, N., and F. Gómez-Marín. 2002. Interspecific interaction and predator avoidance behavior in response to Tayra (Eira barbara) by Mantled howler monkeys (Alouatta palliata). Primates 43:339-341.

Asensio, N., J. Cristobal-Azkarate, J., P. A. Duarte-Dias, J. J. VeA, AND E. Rodríguez-Luna. 2007. Foraging habits of Alouatta palliata mexicana in three forest fragments. Folia Primatologica 78:141-153.

Aureli, F., C. M. Schaffner, J. Verpooten, K. Slater, and G. Ramos-Fernandez. 2006. Raiding parties of male spider monkeys: Insights into human warfare? American Journal of Physical Anthropology 131:486-497.

Aureli, F., And C. M. Schaffner. 2007. Aggression and conflict management at fusion in spider monkeys. Biology Letters 3:147-149.

Bello, J., S. Gallina, and M. Equinua. 2004. Movements of the white-tailed deer and their relationship with precipitation in northeastern México. Interciencia 29:357-361.

Benitez-Malvido, J., A. P. Martínez-Falcón, W. Dattilo, A. M. González-DiPierro, R. L. Estrada, and A. Traveset. 2016. The role of sex and age in the architecture of intrapopulation howler monkey-plant networks in continuous and fragmented rain forests. PeerJ 4:e1809.

Brashear, W. A., R. C. Dowler, and G. Ceballos. 2010. Climbing as an escape behavior in the American hog-nosed skunk, Conepatus leuconotus. Western North American Naturalist 70:258-260.

Breed, M. D., AND J. Moore. 2012. Animal Behavior. Elsevier Academic. San Diego, U.S.A.

Briseño-Jaramillo, M., A. Estrada, and A. Lemasson. 2015. Behavioural innovation and cultural transmission of communication signal in black howler monkeys. Scientific Reports 5:1-10.

Briseño-Jaramillo, M., V. Biquand, A. Estrada, and A. Lemasson. 2017. Vocal repertoire of free-ranging black howler monkeys' (Alouatta pigra): call types, contexts, and sexrelated contributions. American Journal of Primatology 79:1-15.

Briseño-Jaramillo, M., G. Ramos-Fernández, T. M. PalaciosRomo, J. R. Sosa-López, and A. Lemasson. 2018. Age and social affinity effects on contact call interactions in freeranging spider monkeys. Behavioral Ecology and Sociobiology 72:192.

Burton, A. M., S. N. Pérez, and C. C. TOVAR. 2003. Bobcat ranging behavior in relation to small mammal abundance on Colima Volcano, México. Anales del Instituto de Biología, Serie Zoología 74:67-82.

Campbell, C. J., F. Aureli, C. A. Chapman, G. Ramos-Fernández, K. Matthews, S. E. Russo, S. Suarez, and L. Vick. 2005. Terrestrial behavior of Ateles spp. International Journal of Primatology 26:1039-1051.

Carranza, J. 2010. Etología: Introducción a la ciencia del comportamiento. Universidad de Extremadura. Cáceres, España.

Carrillo-Reyes, A., C. Lorenzo, E. J. Naranjo, M. Pando, and T. RıojA. 2010. Home range dynamics of the Tehuantepec Jackrabbit in Oaxaca, México. Revista Mexicana de Biodiversidad 81:143-151.
Chaves, O. M., K. E. Stoner, and V. Arroyo-Rodríguez. 2012. Differences in diet between spider monkey groups living in forest fragments and continuous forest in México. Biotropica 44:105-113.

Cimé-Pool, J. A., S. F. Hernández-Betancourt, and S. M. PerALTA. 2002. Área de actividad de Heteromys gaumeri en una selva mediana subcaducifolia de Yucatán. Revista Mexicana de Mastozoología 6:5-18.

Crespo, R. F., S. B. Linhart, R. J. Burns, and C. Mitchell. 1972. Foraging behavior of the common vampire bat related to moonlight. Journal of Mammalogy 53:366-368.

Cordero, C. 1994. Comentarios de un ecólogo. Revista AIC 21:10-13.

De la Torre, J. A., J. M. Núñez, And R. A. Medellín. 2017. Spatial requirements of jaguars and pumas in Southern México. Mammalian Biology 84:52-60.

Dewsbury, D. A. 1979. Copulatory behavior of four mexican species of Peromyscus. Journal of Mammalogy 60:844-846.

Díaz, J. L. 1994. La mente y el comportamiento animal: Ensayos en etología cognitiva. Fondo de Cultura Económica. Distrito Federal, México.

Dirzo, R., AND M. C. García. 1992. Rates of deforestation in Los Tuxtlas, a neotropical area in Veracruz, México. Conservation Biology 6:84-90.

Dirzo, R., A. Aguirre, and J. C. López. 2009. Diversidad florística de las selvas húmedas en paisajes antropizados. Investigación Ambiental 1:17-22.

Duarte-DiAs, P. A. 2005. Observation of parturition in the Mexican mantled howler monkeys (Alouatta palliata) on the Island of Agaltepec, Veracruz State, México. American Journal of Primatology 65:93-98.

Duarte-Dias, P. A., A. Rangel-Negrín, and D. Canales-EsPINOSA. 2011. Effects of lactation on the time-budgets and foraging patterns of female black howlers (Alouatta pigra). American Journal of Physical Anthropology 145:137-146.

Duarte-Dias, P. A., A. Rangel-Negrín, A Coyohua-Fuentes, and D. Canales-Espinosa. 2014. Factors affecting the drinking behavior of black howler monkeys (Alouatta pigra). Primates 55:1-5.

Duarte-Dias, P. A., B. Cano-Huertes, A. Coyohua-Fuentes, D. R. Chavira-Ramírez, D. Canales-Espinosa, and A. Rangel-NeGRín. 2018. Maternal condition and maternal investment during lactation in mantled howler monkeys. American Journal of Physical Anthropology 167:178-184.

Dunn, J. C., J. CRistóbal-Azkarate, and J. J. VeÀ. 2009. Differences in diet and activity pattern between two groups of Alouatta palliata associated with the availability of big trees and fruit of top food taxa. American Journal of Primatology 71:654-662.

Dunn, J. C., J. Cristóbal-Azkarate, and J. J. VeÀ. 2010. Seasonal variations in the diet and feeding effort of two groups of howlers in different sized forest fragments. International Journal of Primatology 31:887-903.

Dunn, J. C., N. Asensio, V. Arroyo-Rodríguez, S. Schnitzer, and J. Cristóbal-Azkarate. 2012. The ranging costs of a fallback food: liana consumption supplements diet but increases foraging effort in howler monkeys. Biotropica 44:705-714. 
Eibl-Ebesfeldt, I. 1975. Ethology: The biology of behavior. Holt, Rinehart \& Winston. New York, U.S.A

Elizalde-Arellano, C., J. C. López-Vidal, L. Hernández, J. W. Laundré, F. A. Cervantes, and M. Alonso-Spilsbury. 2012. Home range size and activity patterns of bobcats (Lynx rufus) in the southern part of their range in the Chihuahuan Desert, México. The American Midland Naturalist 168:247-264.

Emery Thompson, M. 2019. How can non-human primates inform evolutionary perspectives on female-biased kinship in humans? Philosophical Transactions of the Royal Society B: Biological Sciences 374:20180074.

Escobedo-Morales, L. A., And S. Mandujano. 2007. Conservación del mono aullador en la reserva de la biosfera Los Tuxtlas, Veracruz: un enfoque metapoblacional. Pp. 131-140, in Hacia una cultura de conservación de la diversidad biológica (Halffter, G., S. Guevara, and A. Melic, eds.). Monografías Tercer Milenio. Zaragoza, España.

Estrada, A. 1982. Survey and census of howler monkeys (Alouatta palliata) in the rain forest of "Los Tuxtlas", Veracruz, México. American Journal of Primatology 2:363-372.

Estrada, A. 1984. Resource use by Howler monkeys (Alouatta palliata) in the rain forest of Los Tuxtlas, Veracruz, México. International Journal of Primatology 5:105-131.

Estrada, A., And R. Coates-Estrada. 1985. A preliminary study of resource overlap between howling monkeys ( $A$ ouatta palliata) and other arboreal mammals in the tropical rain forest of Los Tuxtlas, México. American Journal of Primatology 9: 27-37.

Estrada, A., And R. Coates-Estrada. 1988. Tropical rain forest conversion and perspectives in the conservation of wild primates (Alouatta and Ateles) in México. American Journal of Primatology 14:315-327.

Estrada, A., S. Juan-Solano, T. O. Martínez, and R. Coates-EsTRADA. 1999. Feeding and general activity patterns of a howler monkey (Alouatta palliata) troop living in a forest fragment at Los Tuxtlas, México. American Journal of Primatology 48:167-183

Fa, J. E., V. Sanchez-Cordero, and A. Mendez. 1996. Interspecific agonistic behaviour in small mammals in a Mexican highelevational grassland. Journal of Zoology 239:396-401.

Frick, W. F., P. A. Heady III, ANd J. P. Hayes. 2009. Facultative nectar-feeding behavior in a gleaning insectivorous bat (Antrozous pallidus). Journal of Mammalogy 90:1157-1164.

Gallina, S., AND J. Bello Gutiérrez. 2014. Patrones de actividad del venado cola blanca en el noreste de México. Therya 5:423-436.

García-Feria, L. M., B. A. Pérez, and X. Sánchez-Girón. 2016. New record of infanticide in Alouatta pigra: chance of betrayal of altruism. Therya 7:193-196.

Gibson, K. N., L. G. Vick, A. C. Palma, F. M. Carrasco, D. Taub, AND G. Ramos-Fernández. 2008. Intra-community infanticide and forced copulation in spider monkeys: a multi-site comparison between Cocha Cashu, Perú and Punta Laguna, México. American Journal of Primatology 70:485-489.

González-Gallina, A., M. G. Hidalgo-Mihart, F. Pérez-Garduza, J. A. Iglesias-Hernández, A. O. de Ita, A. Chacón-HernánDEZ, AND O. VÁZquez-ZúñIGa. 2018. Home range of a male jaguar spatially associated with the landfill of the city of Playa del Carmen, México. Mammalia 82:54-61.
Gould, E. 1975. Neonatal vocalizations in bats of eight genera. Journal of Mammalogy 56:15-29.

Grajales-Tam, K. M., R. Rodríguez-Estrella, and J. Cancino Hernández. 2003. Dieta estacional del coyote Canis latrans durante el periodo 1996-1997 en el desierto de Vizcaíno, Baja California Sur, México. Acta Zoológica Mexicana 89:17-28.

Greenhall, A. M., U. Schmidt, and W. Lopez-Forment. 1971. Attacking behavior of the Vampire bat, Desmodus rotundus, under field conditions in México. Biotropica 3:136-141.

Greenhall, A. M. 1972. The biting and feeding habits of the Vampire bat, Desmodus rotundus. Journal of Zoology 168:451-461.

Guevara-Chumacero, L. M., R. López-Wilchis, and V. SánchezCordero. 2001. 105 años de investigación mastozoológica en México (1890 - 1995): Una revisión de sus enfoques y tendencias. Acta Zoológica Mexicana 83:35-72.

Hernández Betancourt, S. F., R. López-Wilchis, J. A. Cimé Pool, and S. Medina Peralta. 2003. Área de actividad, movimiento y organización social de Heteromys gaumeri Allen y Chapman, 1897 (Rodentia: Heteromyidae) en una selva mediana subcaducifolia de Yucatán, México. Acta Zoológica Mexicana 90:77-91.

Hernández-Hernández, J. C., J. E. Morales-Mávil, M. Laska, and L. T. Hernández-Salazar. 2018. Diet selectivity in relation to food quality and availability by the endemic Perote squirrel (Xerospermophilus perotensis). Therya 9:121-127.

Hernández-SaintMartín, A. D., O. C. Rosas-Rosas, J. PalacioNúñez, L. A. Tarango-Arámbula, F. Clemente-Sánchez, and A. L. Hoogesteisn. 2013. Activity patterns of jaguar, puma and their potential prey in San Luis Potosi, México. Acta Zoológica Mexicana 29:520-533.

Hernández-SaintMartín, A. D., O. C. Rosas-Rosas, J. PalacioNúñez, L. A. Tarango-Arambula, F. Clemente-Sánchez, and A. L. Hoogesteijn. 2015. Food habits of jaguar and puma in a protected area and adjacent fragmented landscape of northeastern México. Natural Areas Journal 35:308-317.

Herrera, N. 1986. La etología en México. Ciencias 8:9-10.

HıLl, C. M. 2002. Primate conservation and local communities: ethical issues and debates. American Antropologist 104:1184-1194.

Hoffmann, J., R. Palme, And J. A. Eccard. 2018. Long-term dim light during nighttime changes activity patterns and space use in experimental small mammal populations. Environmental Pollution 238:844-851.

Horner, M. A., T. H. Fleming, and C. T. Sahley. 1998. Foraging behaviour and energetics of a nectar-feeding bat, Leptonycteris curasoae (Chiroptera: Phyllostomidae). Journal of Zoology 244:575-586.

Jaffe, K., J. C. Correa, and Z. Tang-Martínez. 2020. Ethology and animal behaviour in Latin America. Animal Behaviour 164:281-291.

Juan, S., A. Estrada, and R. Coates-Estrada. 2000. Contrastes y similitudes en el uso de recursos y patrón general de actividades en tropas de monos aulladores (Alouatta palliata) en fragmentos de selva en Los Tuxtlas, México. Neotropical Primates 8:131-135.

Kelly, R. C. 2000. Warless societies and the origin of war. University of Michigan Press. Ann Arbor, U.S.A. 
LISLE, R. J. 2006. Google Earth: a new geological resource. Geology Today 22:29-32.

Lorenzo, C., AND A. T. Sмiтн. 2019. Lepus flavigularis. The IUCN Red List of Threatened Species 2019: e.T11790A45176906. https://dx.doi.org/10.2305/IUCN. UK.2019-3.RLTS.T11790A45176906.en. Downloaded on 13 November 2020.

Luis, J., A. Carmona, J. Delgado, F. A. Cervantes, and R. CardeNAS. 2000. Parental behavior of the volcano mouse, Neotomodon alstoni (Rodentia: Muridae), in captivity. Journal of Mammalogy 81:600-605.

Luis, J., F. A. Cervantes, M. Martínez, R. Cardenas, J. Delgado, and A. Carmona. 2004. Male influence on maternal behavior and offspring of captive volcano mice (Neotomodon alstoni) from México. Journal of Mammalogy 85:268-272.

Luis, J., L. Ramírez, A. Carmona, G. Ortiz, J. Delgado, and R. CÁrdenas. 2009. Paternal behavior and testosterone plasma levels in the Volcano Mouse Neotomodon alstoni (Rodentia: Muridae). Revista de Biología Tropical 57:433-439.

Luis, J., C. Cadena, B. Zedillo, J. Reyes, G. Ramos, and M. MarTíNEZ. 2012. Testosterone replacement induced paternal behaviour in the Mexican volcano mouse Neotomodon alstoni (Rodentia Muridae). Ethology Ecology and Evolution 24:275-283.

Luis, J., G. Ramos, M. Martínez-Torres, A. Carmona, B. CedilLo, AND J. Delgado. 2017. Testosterone induces paternal behavior in sexually inexperienced males of Neotomodon alstoni (Rodentia: Muridae). Revista de Biología Tropical 65:1419-1427.

Luna-Casanova, A., T. Rioja-Paradela, L. Scott-Morales, and A. Carrillo-Reyes. 2016. Endangered jackrabbit Lepus flavigularis prefers to establish its feeding and resting sites on pasture with cattle presence. Therya 7:277-284.

Marín-Sánchez, A. I., M. Briones-Salas, R. López-Wilchis, and J. Servín. 2015. Ámbito hogareno del coyote (Canis latrans) en un bosque templado de la sierra Madre de Oaxaca, México. Revista Mexicana de Biodiversidad 86:440-447.

Márquez-Arias, A., A. M. Santillán-Doherty, R. V. Arenas-RoSas, M. P. Gasca-Matías, J. Muñoz-Delgado, and J. VillanueVA-VALle. 2014. Efecto del enriquecimiento ambiental en un grupo de monos araña (Ateles geoffroyi) en cautiverio. Salud Mental 37:437-442.

Martínez-Mota, R., C. Valdespino, M. A. Sánchez-Ramos, and J. C. Serio-Silva. 2007. Effects of forest fragmentation on the physiological stress response of black howler monkeys. Animal Conservation 10:374-379.

Mazza, V., M. Dammhahn, E. Lösche, And J. A. Eccard. 2020. Small mammals in the big city: Behavioural adjustments of non-commensal rodents to urban environments. Global Change Biology 26:6326-6337.

McGrew, W. C. 1998. Culture in nonhuman primates? Annual Review of Anthropology 27:301-328.

Medawar, P. B., ANd J. S. Medawar. 1996. De Aristóteles a Zoológicos, un diccionario filosófico de biología. Fondo de Cultura Económica. Distrito Federal, México.

Moreno, C. B., AND J. Muñoz-Delgado. 2007. An account on the history of ethology. Suma Psicológica 14:213-224.

Morete, M. E., D. Abras, And C. C. Martins. 2018. Land-based station studies of aquatic mammals in Latin America: Un- derstanding behavior for conservation. Pp. 77-112, in Advances in Marine Vertebrate Research in Latin America (Rossi-Santos, M. R., and C. W. Finkl, eds.). Springer. Cham, Switzerland.

Morrison, D. W. 1979. Apparent male defense of tree hollows in the fruit bat, Artibeus jamaicensis. Journal of Mammalogy 60:11-15.

Muñoz, D., Y. G. del Valle, B. Franco, A. Estrada, and M. MagaÑA-Alejandro. 2001. Presupuestos de tiempo en una tropa de monos aulladores (Alouatta palliata) en el parque Yumkà, Tabasco, México. Universidad y Ciencia 34:113-123.

Muñoz-Delgado, J., M. Corsi-Cabrera, D. Canales-Espinosa, A. M. Santillán-Doherty, and H. G. Erkert. 2004. Astronomical and meteorological parameters and rest-activity rhythm in the Spider monkey Ateles geoffroyi. Physiology and Behavior 83:107-117.

Muñoz-Delgado, J., J. C. Sánchez-Ferrer, S. Pérez-Galicia, D. Canales-Espinosa, and H. G. Erkert. 2014. Effects of housing conditions and season on the activity rhythm of spider monkeys (Ateles geoffroyi) kept under natural conditions within their distributional range in Central México. Chronobiology International 31:983-995.

Muñoz-Delgado, J., S. Pérez-Galicia, J. C. Sánchez-Ferrer, D. Canales Espinosa, D. and H. G. Erkert. 2018. Diel and infradian (7-day) activity rhythms in Mexican spider monkeys (Ateles geoffroyi) kept with and without visitor contact. American Journal of Primatology 80:e22933.

Nava, V., J. D. Tejero, and C. B. Chávez. 1999. Hábitos alimentarios del cacomixtle Bassariscus astutus (Carnívora: Procyonidae) en un matorral xerófilo de Hidalgo, México. Anales del Instituto de Biología. Serie Zoología 70:51-63. Ortega, J., And H. T. Arita. 1999. Structure and social dynamics of harem groups in Artibeus jamaicensis (Chiroptera: Phyllostomidae). Journal of Mammalogy 80:11731185.

Ortega, J., And H. T. Arita. 2000. Defence of females by dominant males of Artibeus jamaicensis (Chiroptera: Phyllostomidae). Ethology 106:395-407.

Ortega, J., And H. T. Arita. 2002. Subordinate males in harem groups of Jamaican fruit-eating bats (Artibeus jamaicensis): satellites or sneaks? Ethology 108:1077-1091.

Ortega, J., and J. F. Maldonado. 2006. Female interactions in harem groups of the Jamaican fruit-eating bat, Artibeus jamaicensis (Chiroptera: Phyllostomidae). Acta Chiropterologica 8:485-495.

Ortega, J., And J. L. Martínez-Rodríguez. 2011. Conductas de apareamiento y agresión entre machos en una colonia de Nyctinomops laticaudatus (Chiroptera: Molossidae) en México. Mastozoología Neotropical 18:95-103.

Packard, R. L. 1958. Carnivorous behavior in the mexican ground squirrel. Journal of Mammalogy 39:154.

Pastor-Nieto, R. 2001. Grooming, kinship, and co-feeding in captive spider monkeys (Ateles geoffroyi). Zoo Biology 20:293-303.

Pérez-Galicia, S., M. Miranda-Anaya, D. Canales-Espinosa, And J. Muñoz-Delgado. 2017. Visitor effect on the behavior of a group of spider monkeys (Ateles geoffroyi) maintained at an island in Lake Catemaco, Veracruz/México. Zoo Biology 36:360-366. 
Pinacho-Guendulain, B., and G. Ramos-Fernández. 2017. Influence of fruit availability on the fission-fusion dynamics of spider monkeys (Ateles geoffroyi). International Journal of Primatology 38:466-484.

Pozo-Montuy, G., And J. C. Serio-Silva. 2006. Comportamiento alimentario de monos aulladores negros (Alouatta pigra Lawrence, Cebidae) en hábitat fragmentado en Balacán, Tabasco, México. Acta Zoológica Mexicana (n. s.) 22:53-66.

Ramírez-Pulido, J., N. Gonzáles-Ruiz, and D. F. García-MendoZA. 2017. References on mexican mammals: Origin and Impact. Therya 8:151-170.

Rangel-Negrín, A., A. Coyohua-Fuentes, R. Chavira, D. Canales-Espinosa, and P. A. Duarte-Dias. 2014. Primates living outside protected habitats are more stressed: the case of black howler monkeys in the Yucatán Peninsula. PLoS One 9:e112329.

Rangel-Negrín, A., E. Flores-Escobar, A. Coyohua-Fuentes, D. R. Chavira-Ramírez, D. Canales-Espinosa, and P. A. DuarteDiAs. 2015. Behavioural and glucocorticoid responses of a captive group of Spider monkeys to short-term variation in food presentation. Folia Primatologica 86:433-445.

Rangel-Negrín, A., A. C. Fuentes, D. C. Espinosa, and P. A. Duarte-Dias. 2016. The loss of behavioral diversity as a consequence of anthropogenic habitat disturbance: the social interactions of black howler monkeys. Primates 57:9-15.

Rangel-Negrín, A., A. Coyohua-Fuentes, D. Canales-Espinosa, and P. A. Duarte-Dias. 2018. The influence of leaf consumption on time allocation in Black Howler Monkeys ( $\mathrm{Al}$ ouatta pigra). Folia Primatologica 89:111-122.

Rebecchini, L., C. M. Schaffner, And F. Aureli. 2011. Risk is a component of social relationships in spider monkeys. Ethology 117:691-699.

Reyna-Hurtado, R., E. Rojas-Flores, And G. W. Tanner. 2009. Home range and habitat preferences of white-lipped peccaries (Tayassu pecari) in Calakmul, Campeche, México. Journal of Mammalogy 90:1199-1209.

Reynoso-Cruz, J. E., A. Rangel-Negrín, A. Coyohua-Fuentes, D. Canales-Espinosa, and P. A. Duarte-Dias. 2016. Measures of food intake in mantled howling monkeys. Primates 57:161-166.

Rioja-Paradela, T. M., L. M. Scott-Morales, M. Cotera-CorRea, ANd E. Estrada-Castillón. 2008a. Reproduction and behavior of the Mexican prairie dog (Cynomys mexicanus). The Southwestern Naturalist 53:520-523.

Rioja-Paradela, T., C. Lorenzo, E. Naranjo, L. Scott, and A. Carrillo-Reyes. 2008b. Polygynous mating behavior in the endangered Tehuantepec jackrabbit (Lepus flavigularis). Western North American Naturalist 68:343-349.

Rioja-Paradela, T., C. Lorenzo, E. Naranjo, L. Scott, and A. Carrillo-Reyes. 2011. Breeding and parental care in the endangered Tehuantepec jackrabbit (Lepus flavigularis). Western North American Naturalist 71:56-66.

Rodríguez-Luna, E., A. Shedden, and B. Solórzano-García. 2013. A region-wide review of Mesoamerican primates: Prioritizing for conservation. Pp. 46-55, in Primates in fragments (Marsh, L. K., and C. A. Chapman, eds.). Springer Science + Business Media. New York, U.S.A.
Russell, R. J., AND J. S. Findley. 1954. Swimming ability of the grasshopper mouse. Journal of Mammalogy 35:118-119.

Sánchez-Ferrer, J. C., J. Servín, J. Muñoz-Delgado, C. Murata, I. Méndez Ramírenz, J. SÁnchez-Robles, and R. López-Wilchis. 2016. Variations in the locomotor activity of the Mexican wolf (Canis lupus baileyi) respect to moon periodicity: a study in an outdoor enclosure. Biological Rhythm Research 47:539-551.

Santorelli, C. J., C. M. Schaffner, and F. Aureli. 2011. Universal behaviors as candidate traditions in wild spider monkeys. PLoS One 6:e24400.

Santorelli, C. J., F. Aureli, G. Ramos-Fernández, and C. M. SChAFFner. 2013. Individual variation of whinnies reflects differences in membership between spider monkey (Ateles geoffroyi) communities. International Journal of Primatology 34:1172-1189.

Santos-Moreno, A., and A. E. Santiago-Marcial. 2012. Área de actividad y movimientos de Liomys irroratus (Rodentia: Heteromyidae) en una selva mediana de Tuxtepec, Oaxaca, México. Revista Mexicana de Biodiversidad 83:496-502.

Schaffner, C. M., K. Y. Slater, And F. Aurelı. 2012. Age related variation in male-male relationships in wild spider monkeys (Ateles geoffroyi yucatanensis). Primates 53:49-56.

Secretaria de Medio ambiente y recursos naturales. 2010. Norma Oficial Mexicana NOM-059-SEMARNAT-2010. Protección ambiental -especies nativas de México de flora y fauna silvestres- categorías de riesgo y especificaciones para su inclusión, exclusión o cambio- lista de especies en riesgo. Secretaría del Medio Ambiente y Recursos Naturales. México. 30 December, 2010.

Serio-Silva, J. C., AND V. Rico-Gray. 2000. Use of a stream by Mexican howler monkeys. The Southwestern Naturalist 45:332-333.

Servín, J. 1991. Algunos aspectos de la conducta social del lobo mexicano (Canis lupus baileyi) en cautiverio. Acta Zoológica Mexicana 43:1-43.

Servín, J. 1997. El periodo de apareamiento, nacimiento y crecimiento del lobo mexicano (Canis lupus baileyi). Acta Zoológica Mexicana 71:45-56.

Servín, J. 2000. Duration and frequency of chorus howling of the Mexican wolf (Canis lupus baileyi). Acta Zoológica Mexicana 80:223-231.

Servín, J., A. Bejarano, N. Alonso-Pérez, and E. Chacón. 2014. El tamaño del ámbito hogareño y el uso de hábitat de la zorra gris (Urocyon cinereoargenteus) en un bosque templado de Durango, México. Therya 5:257-269.

Servín, J., And C. Huxbey. 1991. La dieta del coyote en un bosque de encino-pino de la Sierra Madre Occidental de Durango, México. Acta Zoológica Mexicana (n. s.) 44:1-26.

Servín, J., ANd C. Huxley. 1995. Coyote home range size in Durango, México. Zeitschrift fuer Säugetierkunde 60:119-120.

Slater, K. Y., C. M. Schaffner, And. F. Aurelı. 2007. Embraces for infant handling in spider monkeys: evidence for a biological market? Animal Behaviour 74:455-461.

Slater, K. Y., C. M. Schaffner, And F. Aureli. 2008. Female-directed male aggression in wild Ateles geoffroyi yucatanensis. International Journal of Primatology 29:1657-1669.

Slater, K. Y., C. M. Schaffner, And F. Aureli. 2009. Sex differences in the social behavior of wild spider monkeys (Ateles 
geoffroyi yucatanensis). American Journal of Primatology 71:21-29.

Smith-Aguilar, S. E., G. Ramos-Fernández, and W. M. Getz. 2016. Seasonal changes in socio-spatial structure in a group of free-living spider monkeys (Ateles geoffroyi). Plos One 11:e0157228.

Smith, J. E., J. R. Estrada, H. R., Richards, S. E. Dawes, K. Mitsos, AND K. E. Holekamp. 2015. Collective movements, leadership and consensus costs at reunions in spotted hyaenas. Animal Behaviour 105:187-200.

Soares, P. F. R., C. Q. Monteiro, A. L. Henriques, A. C. S. Formento, F. I. B. Brandão, and P. I. S. L. Costa. 2016. Trends in the Brazilian journal Revista de Etologia: A review from 1998 to 2014. Current Ethology 15:7e13.

Soto, M. A., C. Vázquez, X. Ramos, L. Yáñez, M. de Lourdes, and M. A. Armella. 2013. Presencia de doble estro anual en una hembra de lobo mexicano (Canis lupus baileyi) en cautiverio. Therya 4:539-549.

Tokuyama, N., AND T. Furuichi. 2017. Leadership of old females in collective departures in wild bonobos (Pan paniscus) at Wamba. Behavioral Ecology and Sociobiology 71:55.

Valero, A., C. M. Schaffner, L. G. Vick, F. Aurel, and G. RamOS-FeRnANDEZ. 2006. Intragroup lethal aggression in wild spider monkeys. American Journal of Primatology 68:732-737.

Valero, A., ANd R. W. Byrne. 2007. Spider monkey ranging patterns in Mexican subtropical forest: do travel routes reflect planning? Animal Cognition 10:305-315.

Van Belle, S., A. Estrada, T. E. Ziegler, and K. B Strier. 2009a. Social and hormonal mechanisms underlying male reproductive strategies in black howler monkeys (Alouatta pigra). Hormones and Behavior 56:355-363.

Van Belle, S., A. Estrada, T. E. Ziegler, and K. B. Strier. 2009 b. Sexual behavior across ovarian cycles in wild black howler monkeys (Alouatta pigra): male mate guarding and female mate choice. American Journal of Primatology 71:153-164.

Van Belle, S., A. Estrada, and P. A. Garber. 2013. Collective group movement and leadership in wild black howler monkeys (Alouatta pigra). Behavioral Ecology and Sociobiology 67:31-41.

Van Belle, S., P. A. Garber, A. Estrada, and A. Di Fiore. 2014. Social and genetic factors mediating male participation in collective group defence in black howler monkeys. Animal Behaviour 98:7-17.

Watson, C. F. I., and C. A. Caldwell. 2009. Understanding behavioral traditions in primates: Are current experimental approaches too focused on food? International Journal of Primatology 30:143-167.

Watts, D. P., M. Muller, S. J. Amsler, G. Mbabazi, and J. C. Mitanı. 2006. Lethal intergroup aggression by chimpanzees in Kibale National Park, Uganda. American Journal of Primatology 68:161-180.

Wierucka, K., B. J. Pitcher, R. Harcourt, and I. Charrier. 2018. Multimodal mother-offspring recognition: the relative importance of sensory cues in a colonial mammal. Animal Behaviour 146:135-142.

Wımsatt, W. A. 1969. Transient behavior, nocturnal activity patterns and feeding efficiency of vampire bats (Desmo- dus rotundus) under natural conditions. Journal of Mammalogy 50:233-244.

Associated editor: Jorge Servín

Submitted: January 30, 2021; Reviewed: February 15, 2021.

Accepted: August 15, 2021; Published on line: September 12, 2021. 